\title{
Increasing Mathematics Learning Outcomes on Fraction Materials Through Discovery Learning Model
}

\section{Imam Syarifudin}

\author{
SD Negeri Randusanga Wetan 01 \\ abunisrina4@gmail.com
}

\section{Article History}

received 3/12/2020

\begin{abstract}
Mathematics subject matter of fractions with the Discovery Learning learning model. The research conducted was Classroom Action Research with 2 cycles, with each cycle consisting of 2 meetings. Each cycle includes the stages of planning, implementation, observation and reflection. Each meeting was conducted pre-test and post-test to determine the progress of students. In Cycle I, students who completed the post test were 68.18\%. In Cycle II, the students who completed the post test were $90.91 \%$. From the implementation of these 2 cycles, it is shown that the Discovery Learning model can improve the learning outcomes of students in Mathematics in Class $V$ fractions.
\end{abstract}

Keywords: hasil belajar, discovery learning, matematika

\begin{abstract}
Abstrak
ujuan dari penellitan ini adalah untuk meningkatakan hasil belajar peserta didik pada mata pelajaran Matematika Kelas V materi pecahan dengan model pembelajaran Discovery Learning. Penelitian yang dilakukan adalah Penelitan Tindakan Kelas (Classroom Action Research) sebanyak 2 siklus, dengan setiap siklusnya terdiri dari 2 pertemuan. Setiap siklus meliputi tahap perencanaan, pelaksanaan, observasi dan refleksi. Setiap pertemuan dilakukan pre test dan post test untuk mengetahui perkembangan peserta didik. Pada Siklus I peserta didik yang tuntas setelah melaksanakan post test sebesar $68,18 \%$. Pada Siklus II peserta didik yang tuntas setelah melaksanakan post test sebesar $90,91 \%$. Dari pelaksaan 2 siklus ini menunujukkan bahwa model Discovery Learning dapat meningkatkan hasil belajar peserta didik mata pelajaran Matematika pada meteri pecahan Kelas $\mathrm{V}$.
\end{abstract}

Kata kunci: hasil belajar, discovery learning, matematika 


\section{PENDAHULUAN}

Dalam Undang-Undang No. 20 Tahun 2003 (Fokusindo Mandriri, 2012:2) Pasal 1 Pendidikan adalah suatu usaha sadar dan terencana untuk mewujudkan suasana belajar dan proses pembelajaran agar peserta didik secara aktif mengembangkan potensi dirinya untuk memiliki kekuatan spiritual, keagamaan, pengendalian diri, kepribadian, kecerdasan, akhlak mulia, serta keterampilan yang diperlukan dirinya, masyarakat, bangsa, dan negara. Untuk mengembangkan potensinya peserta didik harus belajar. Belajar menurut Gagne (Suprijono, 2012: 2) adalah perubahan disposisi atau kemampuan yang dicapai seseorang melalui aktivitas. Perubahan disposisi tersebut bukan diperoleh langsung dari proses pertumbuhan seseorang secara alamiah. Namun, perubahan disposisi atau kemampuan terjadi karena belajar. Nasution (1992:3) dalam Uno,Hamzah.B dan Mohamad, Nurdin (2012:141) mengatakan belajar adalah aktivitas yang menghasilkan perubahan pada diri individu yang belajar, baik aktual maupun potensial. Proses belajar yang dilaksanakan peserta didik akan menghasilkan hasil belajar. Suprijono,Agus (2012 :5-7) mengemukakan bahwa ,hasil belajar adalah pola-pola perbuatan, nilai-nilai, pengertian-pengertian, sikap-sikap, apresiasi, dan keterampilan. Hasil belajar berupa :Informasi verbal yaitu kapabilitas mengungkapkan pengetahuan dalam bentuk bahasa, baik lisan maupun tertulis;Keterampilan intelektual yaitu kemampuan mempresentasikan kkonsep dan lambang;Strategi kognitif yaitu kecakapan menyalurkan dan mengarahkan aktivitas kognitif sendiri;Keterampilan motorik yaitu kemampuan melakukan serangkaian gerak jasmani dalam urusan dan koordinasi, sehingga terwujud otomatisme gerak jasmani.;Sikap adalah kemampuan menerima atau menolak objek berdasarkan penilaian terhadap objek tersebut.

Kurikulum 2013 di tingkat Sekolah Dasar kelas tinggi pelajaran Matematika berdiri sendiri. Ruseffendi (1989:23) dalam Karso,dkk (2011:1.39) menyatakan bahwa matematika itu terorgansasikan dari unsur-unsur yang tidak didefinisikan, definisidefinisi, aksioma-aksioma, dan dalil-dalil, di mana dalil-dalil setelah dibuktikan kebenarannya berlaku secara umum, karena itulah matematika sering disebut ilmu deduktif. Andi Hakim Nasution (1980:12) dalam Karso,dkk (2011:1.39) mangatakan istilah matematika berasal dari bahasa Yunani "mathein" atau "manthenein" artinya "mempelajari", namun diduga kata itu ada hubungannya dengan kata Sansekerta "medha" atau "midya" yang artinya "kepandaian", "ketahuan", "intelegensi" .

Sesuai Silabus Kurikulum 2013 pada Semester I Bab 2 dijelaskan bahwa cakupan materi tentang Operasi Bilangan Pecahan dengan KD.3.2 menjelaskan dan melakukan penjumlahan dan pengurangan dengan dua pecahan dengan penyebut berbeda. Hasil belajar peserta didik pada materi tersebut tidak sesuai dengan KKM yang telah ditetapkan sekolah. Pada kegiatan Prasiklus ketuntasan belajar sebesar 18,18\% dengan rata-rata 62,50. Rendahnya hasil belajar ini tentunya dipicu oleh beberapa faktor diantarnya guru masih menggunakan metode ceramah, guru menjadi figur yang dominanan dalam proses pembelajaran, minimnya penggunaan model pembelajaran yang sesuai dengan kondisi peserta didik yang diajar.

Untuk meningkatkan hasil belajar yang diharapkan maka pembelajaran harus berfokus pada peserata didik, menggugah daya nalar, menumbuhkan kreatifitas dan juga menyenangkan. Salah satunya adalah model pembelajaran Discovery Learning. Slameto (2015:24) menyatakan dalam model Discovery Learning, tidak semua yang dipelajari harus dipresentasikan dalam bentuk keseluruhan dan final, beberapa bagian harus dicari,diidentifikasi sendiri oleh peserta didik. Sund dalam Roestiyah (2012:20) mengatakan bahwa, Discovery adalah proses mental dimana siswa mampu memadukan suatu konsep maupun prinsip. Proses mental tersebut diantaranya mencakup kegiatan: mengamati, mencerna, mengerti, mengelompokkan, membuat dugaan, menjelaskan, mengukur, membuat kesimpulan dan lain-lain. Roestiyah, (2012:21) menyatakan bahwa metode discovery learningmemiliki keunggulan diantaranya yakni: (1) mengasah kognitif siswa, (2) pengetahuan yang telah dipelajari 
peserta didik bertahan lama, (3) semangat belajar peserta didika akan meningkat, (4) mengembangkan diri peserta didik, (5) motivasi peserta didik meningkat, (6) kepercayaan diri peserta didik meningkat, (7) merupakan model pembelajaran yang berfokus pada peserta didik.

Dari berbagai pendapat tersebut maka dapat ditegaskan bahwa model pembelajaran Discovery adalah pembelajaran dimana peserta didik dituntut aktif untuk menemukan sendiri konsep atau prinsip. Pembelajaran ini terdapat berbagai keunggulan dan membuat peserta didik lebih mandiri.

\section{METODE}

Penelitan ini adalah penelitaian tindakan kelas (Classroom Action Research) dengan menerapkan model pembelajaran Discovery Learning. Menurut Aqib (2011), penelitian tindakan kelas adalah penelitian yang dilakukan oleh guru di kelasnya sendiri melalui refleksi diri dengan tujuan untuk memperbaiki kinerjanya sehingga hasil belajar siswa meningkat. Analisis penelitian menggunakan analisis deskriptif, akuantitafif, dan kualitatif dimana dalam penelitian ini selain penyajian hasil berupa data maupun angka peneliti juga menentukan bagaimana cara pengolahan hasil penelitian yakni dengan membuat analisisnya dengan menerapkan model penelitian Discovery Learing .Penelitian ini dilaksanakan pada peserta didik kelas V SD Negeri Randusanga Wetan 01 Tahun Pelajaran 2020/2021 selama 2 siklus dengan 2 pertemuan setiap siklusnya. Siklus I dilaksanakan pada tanggal 7 dan 8 September 2020. Siklus II dilaksanakan pada tanggal 21 dan 22 September 2020. Teknik pengumpulan data dilaksanakan dengan observasi dan test dengan pre test pada bagian awal dan post test bagian akhir. Pada kegiatan observasi beberapa hal yang dilaksakan adalah pengamatan sikap peserta didik dalalm kegaiatan pembelajaran dan penilaian keterampilan disamping itu kesesuaian menerapan model Discovery learning juga masuk dalam obeservasi.

\section{HASIL DAN PEMBAHASAN}

Dalam kegiatan Siklus I kegiatan pembelajaran dilaksanakan dalam 2 kali pertemuan, pada setiap pertemuan di adakan kegiatan pre test dan post tes dengan mencantumkan prosentase pada setiap pertemuannya yang berguna untuk membadingkan tingkat ketercapaian hasil berlajar dan bermanfaat untuk mengetahui perkembangan setiap peserta didik dalam setiap pembelajarannya. Kegiatan Siklus I materi Matematika tentang penjumlahan dan pengurangan dua pecahan dengan penyebut berbeda. Discovery learning digunakan sebagai model dalam pembelajaran Matematika pada materi ini. Adapun langkath Discovery Learning dimulai dengan stimulasi (stimulsi atau pemberian rangsangan). Peserta didik dihadapkan sesuatu yang menimbulkan kebingungan kemudian dilanjutkan untuk tidak memberi generalisasi. , Pernyataan/identifikasi masalah (problem statement). Problem statement yaitu pernyataan atau identifikasi masalah guru memberikan kesempatan kepada siswa untuk mengidentifikasi masalah-masalah yang relevan dengan bahan pembelajaran kemudian salah satunya dipilih dan dirumuskan dalam bentuk hipotesis. Tahap ini siswa diberikan kesempatan untuk mengumpulkan berbagai informasi yang relevan, membaca literatur, mengamati objek, wawancara, melakukan uji coba sendiri, untuk menjawab pertanyaan, atau membuktikan benar tidaknya hipotesis.Pengumpulan data (data collection). Tahap ini berfungsi sebagai pembentukan konsep dan generalisasi sehingga siswa akan mendapatkan pengetahuan baru dari alternatif jawaban yang perlu mendapatkan pembuktian secara logis. Pengolahan data (data processing). Pada tahap ini siswa melakukan pemeriksaan secara cermat, untuk membuktikan benar atau tidaknya hipotesis yang telah ditetapkan dengan temuan alternatif kemudian dihubungkan dengan hasil pengolahan data. Pembuktian (verification), Menarik kesimpulan (generalization). Tahap ini proses menarik kesimpulan yang dapat dijadikan prinsip umum dan berlaku 
untuk semua kejadian atau masalah yang sama dengan memperhatikan hasil verifikasi . Berikut ini disajikan hasil belajar peserta didik pada kegiatan siklus I yang bisa dilihat pada tabel berikut.

Tabel 1. Hasil Belajar Peserta Didik Siklus I

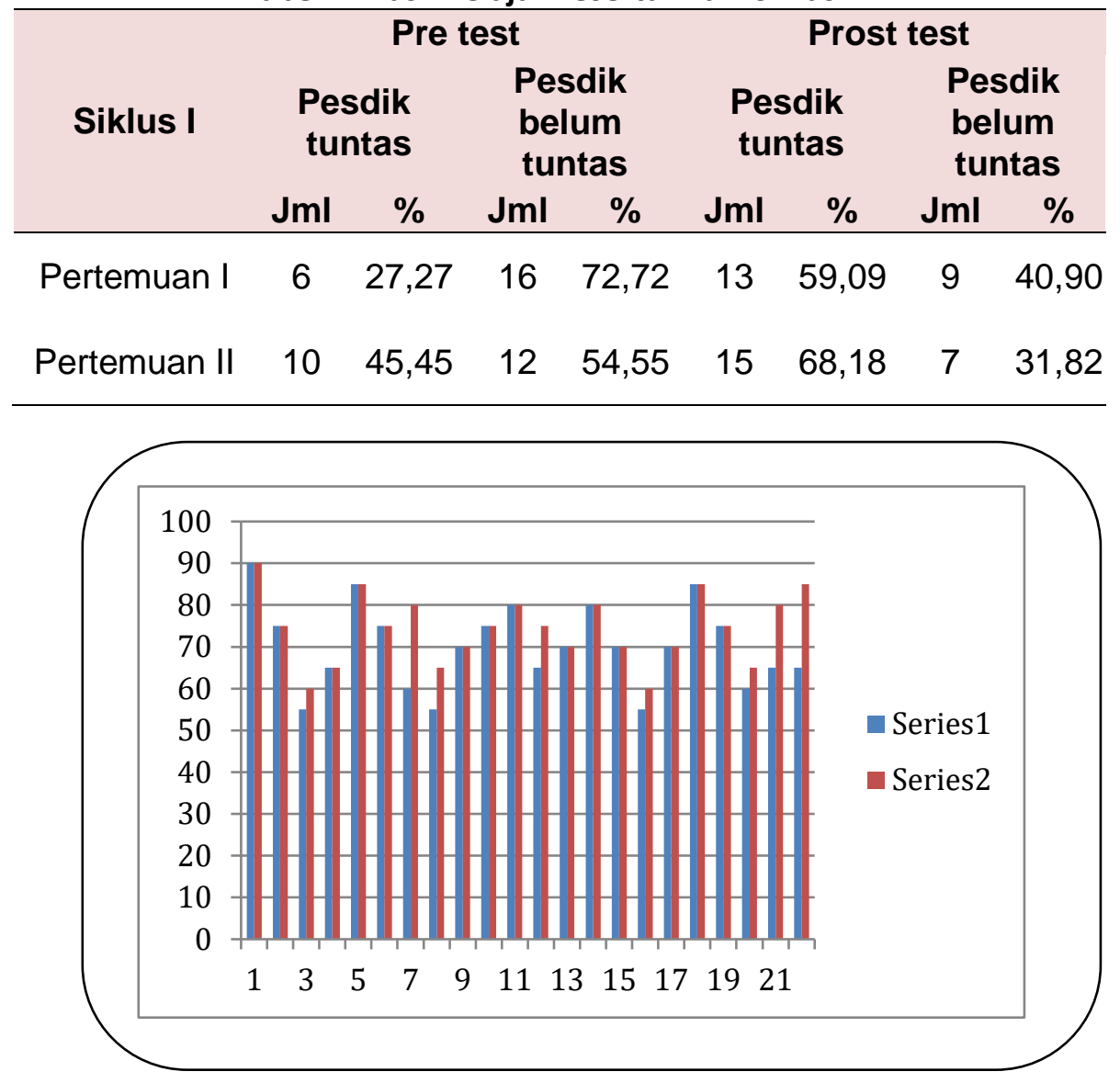

Gambar 1. Hasil Observasi Keterampilan Proses Sains

Dengan melihat hasil belajar peserta didik pada tabel I di atas maka terjadi peningkatan antara pre test dan post test pada pertemuan 1 peserta didik sudah mengalami peningkatan hasil belajarnya. Peserta didik mengalami peningkatan hasil belajar pada pertemuan 1. Ketuntasan klasikal juga mengalami peningkatan, pada pre test hanya terdapat 6 anak yang sudah tuntas dengan prosentase $27,27 \%$, tetapi pada post test bertambah menjadi 13 anak yang sudah tuntas dengan prosentase $59,09 \%$ dengan Kriteria Ketuntasan Minimal (KKM) sebesar 65. Demikian juga pada pertemuan 2 jumlah peserta didik yang sudah tuntas mengalami peningkatan. Pada pre test ada 10 anak yang baru tuntas dengan prosentase $45,45 \%$, sudah meningkat menjadi 15 anak yang tuntas setelah melaksanakan post test dengan prosentase $68,18 \%$. Perbandingan antara hasil post test pada pertemuan 1 dan pertemuan 2 juga terdapat perbedaan. Pada pertemuan 1 peserta didik yang sudah tuntas hanya ada 13 anak, sedangkan pada pertemuan 2 sudah meningkat menjadi 15 anak. Persentase ketuntasan klasikalnya meningkat, jika pertemuan 1 hanya 59,09\% maka pada pertemuan 2 menjadi $68,18 \%$.

Berdasarkan hasil refleksi pada siklus I, maka diputuskan untuk melanjutkan kegiatan ke siklus II dikarenakan hasil belajar peseta didik pada siklus I belum mencapai Kriteria Ketuntasan Minimum (KKM) yang diharapkan. Pada kegiatan Siklus 
II materi yang disajikan masih membahas tentang pejumlahan dan pengurangan dua pecahan dengan penyebut berbeda. Pembelajaran dengan model Discovery Learning dilaksanakan dengan 6 langkah Discovery Learning secara berurutan seperti siklus I Berikut ini adalah hasil belajar peserta didik pada siklus II yang bisa dilihat pada tabel berikut.

Tabel 2. Hasil Belajar Peserta Didik Siklus II

\begin{tabular}{cccccccccc}
\hline & \multicolumn{3}{c}{ Pre test } & \multicolumn{3}{c}{ Prost test } \\
Siklus I & \multicolumn{2}{c}{$\begin{array}{c}\text { Pesdik } \\
\text { tuntas }\end{array}$} & \multicolumn{2}{c}{$\begin{array}{c}\text { Pesdik } \\
\text { belum } \\
\text { tuntas }\end{array}$} & \multicolumn{2}{c}{$\begin{array}{c}\text { Pesdik } \\
\text { tuntas }\end{array}$} & \multicolumn{2}{c}{$\begin{array}{c}\text { Pesdik } \\
\text { belum } \\
\text { tuntas }\end{array}$} \\
& Jml & $\%$ & Jml & $\%$ & Jml & $\%$ & Jml & $\%$ \\
\hline Pertemuan I & 14 & 63,64 & 8 & 36,36 & 17 & 77,27 & 5 & 22,73 \\
Pertemuan II & 15 & 68,18 & 7 & 31,82 & 20 & 90,91 & 2 & 09,09 \\
\hline
\end{tabular}

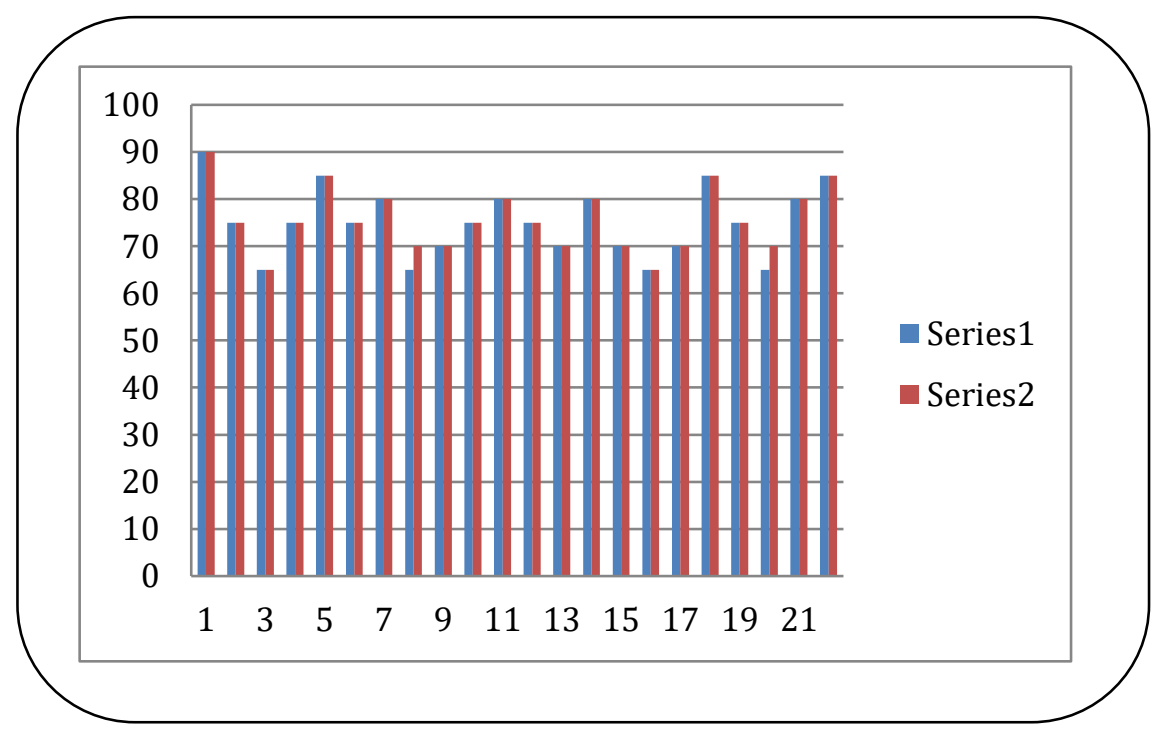

Gambar 1. Hasil Observasi Keterampilan Proses Sains

Dengan melihat hasil belajar peserta didik pada tabel 2 di atas maka terjadi peningkatan antara pre test dan post test pada pertemuan 1 peserta didik sudah mengalami peningkatan hasil belajarnya. Peserta didik mengalami peningkatan hasil belajar pada pertemuan 1. Ketuntasan klasikal juga mengalami peningkatan, pada pre test hanya terdapat 14 anak yang sudah tuntas dengan prosentase $63,64 \%$, tetapi pada kegiatan post test hasilnya meningkat menjadi 17 anak yang sudah tuntas dengan prosentase 77,27\% dengan Kriteria Ketuntasan Minimal (KKM) sebesar 65. Demikian juga pada pertemuan 2 jumlah peserta didik yang sudah tuntas mengalami peningkatan. Pada pre test ada 15 anak yang baru tuntas dengan prosentase 68,18\% , meningkat menjadi 20 anak yang tuntas setelah melaksanakan post test dengan prosentase $90,91 \%$. Perbandingan antara hasil post test pada pertemuan 1 dan pertemuan 2 juga terdapat perbedaan. Pada pertemuan 1 peserta didik yang sudah tuntas hanya ada 17 anak, sedangkan pada pertemuan 2 sudah meningkat menjadi 20 anak. Persentase ketuntasan klasikalnya meningkat, jika pertemuan 1 hanya $77,27 \%$ maka pada pertemuan 2 menjadi 90,91\%, sedangkan peserta yang gagal 
memenuhi Ketuntasan Kriteria Minimum (KKM) pada kegitan post test siklus 2 hanya 2 peserta dari 22 peserta didik di kelas 5 .

Berdasarkan hasil refleksi pada siklus 2 maka ketuntansan hasil belajar peserta didik sudah tercapai dengan dengan hasil $90,91 \%$ untuk peserta didik tuntas sedang prosentase ketidak tuntasan sebeser 09,09\%. 2 Siklus yang sudah dilaksanakan menggunakan model Discovery Learning dengan menggunakan 6 langkah Kegiatan yang dilaksanakan pada Siklus I dan Siklus II merapkan 6 langkah yang dimulai dari stimulasi sampai dengan menarik kesimpulan. Dengan penerapan model Discovery Learning. Serta menerpkan langkah-langkah dalam model ini akan menjadikan peserta didik lebih mandiri. Peserta didik mampu membuktikan sendiri dan menemukan hasil dengan kemampuan sendiri. Hal ini sesuai dengan Kelebihan Discovery Learning (Suherman dkk, 2001:179),diantaranya: Peserta didik aktif dalam KBM (Kegiatan Belajar Mengajar), karena mereka berpikir dan memakai kemampuan untuk bisa menemukan hasil akhirnya; Peserta didik memahami materi pembelajaran dengan baik, karena mereka menjalani proses penemuan hasil sehingga mereka bisa mengingatnya terus.;Akan muncul rasa puas karena sudah menemukan hasil sendiri dan nantinya akan memotivasi penemuan lainnya sehingga siswa akan lebih giat belajar.;Peserta didik mendapatkan pengetahuan dengan Discovery Learing yang lebih bisa menyampaikan penbgetahuan dengan berbagai konteks.;Pembelajaran penemuan ini mendidik peserta didik untuk banyak belajar secara mandiri dengan demikian model pembelajaran Discovery Learning dapat meningkatakan hasil belajar peserta didik pada mata pelajaran Matematika materi penjumlahan dan pengurangan dengan 2 penyebut berbeda.

\section{SIMPULAN}

Penerapan model pembelajaran Discovery Leraning yang dilaksanan pada Siklus I dan Siklus II dengan 2 pertemuan setiap tahapnya ternyata dapat meningktakan hasil belajar peserta didik Kelas $\mathrm{V}$ pada mata pelajaran Matematik materi penjumlahan dan pengurangan pecahan dengan dengan dua penyebut berbeda. Peningkatan hasil belajar pada materi ini terjadi karena pembelajaran berpusat pada peserta didik .Peserta didik membangun pengetahuan sendiri dan guru hanya bertindak sebagai fasiliitor selama kegiatan belajar mengajar. Peserta didik diberi stimulasi pada awal pembelajaran, adanya identifikasi masalah pada materi yang diberikan, kemudian kengumpulan data, setah itu data diolah untuk membuktikan hasil diakhir dengan kesimpulan. Berdasarkan penelitan yang dilaksanakan salah satu model pembelajaran yang perlu dikuasai guru diantarnya model Discovery Learning karena model ini sesuai kedaan peserata didik pada saat ini.

\section{DAFTAR PUSTAKA}

Depdiknas.(2012).Undang-undang Sistem Pendidikan Nasional.Bandung. Fokusindo Mandiri

Aqib, Zainal, dkk. (2011) Penelitian Tindakan Kelas untuk Guru SD, SLB, dan TK. Bandung: Yrama Widya..Diakses dari https://www.kajianpustaka.com/2019/03/penelitian-tindakan-kelas-ptk.html

Karso,dkk.(2011) Pendidikan Matematika Penerbit Universitas Terbuka.Jakarta

Roestiyah. (2012) Strategi Belajar Mengajar. Jakarta. Rineka Cipta. Diakses dari https://meenta.net/pembelajaran-discovery-menurut-ahli/

Slameto.(2015) . Belajar dan Faktor-faktor yang Memengaruhinya. Jakarta: Rineka Cipta. Diakses dari https://meenta.net/pembelajaran-discovery-menurut-ahli/

Suherman, dkk. (2001) Keunggulan Metode Discovery.Diakses dari https://www.pelajaran.co.id/discovery-learning/ 
SHEs: Conference Series 3 (4) (2020) 646- 652

Suprijono, Agus.(2012).Cooperative Learning Teori dan Aplikasinya. Surabaya: Pustaka Belajar.

Uno, Hamzah.B dan Mohamad,Nurdin.(2012) Belajar dengan Pendekatan PAIKEM .Jakarta.Bumi Aksara 